\title{
MEMBACA CITRA INDONESIA DALAM ARSIP AUDIO VISUAL KEMENTERIAN PARIWISATA
}

\author{
Rina Widiastuti \\ Program Studi Bahasa Prancis, Sekolah Vokasi, Universitas Gadjah Mada \\ rina.widi.astuti@ugm.ac.id \\ Lastria Nurtaanzila \\ Program Studi Kearsipan, Sekolah Vokasi, Universitas Gadjah Mada \\ lastrianurtanzila@ugm.ac.id
}

\begin{abstract}
This article aims to explore the image of Indonesia created by the Ministry of Tourism through the audio-visual archive, which is stored and published on its official youtube channel. This study is in response to the Indonesian government's policy to improve the image of Indonesia and build a strong nation brand for Indonesia to compete in global level. Using the content analysis method, I analyzed the videos on the Indonesia.Travel channel to reveal the image of Indonesia promoted by the Indonesian government. Based on the icons that appear on the 218 videos on the youtube channel, we can find five main icon categories. The iconic categories are natural beauty, cultural uniqueness, resident friendliness, delicacy of food, and environmental peace. These five iconic categories build one image of Indonesia as a wonderful country. This is in accordance with the official slogan used by the Ministry of Tourism to promote Indonesia, namely Wonderful Indonesia.
\end{abstract}

Keywords: image, content analysis, video, youtube

\section{Intisari}

Artikel ini bertujuan untuk mengeksplorasi arsip audio-visual yang disimpan dan dipublikasikan di saluran resmi youtube. Penelitian ini merupakan tanggapan terhadap kebijakan bahasa Indonesia untuk meningkatkan citra Indonesia dan membangun kebangsaan yang kuat bagi Indonesia untuk bersaing di tingkat global. Menggunakan metode analisis isi, saya menganalisis video di Indonesia. Saluran perjalanan untuk mengungkap citra Indonesia dipromosikan oleh pemerintah Indonesia. Berdasarkan ikon yang muncul pada 218 video di saluran YouTube, kita dapat menemukan lima kategori ikon utama. Kategori ikonik adalah keindahan alam, keunikan budaya, keramahan penduduk, kelezatan makanan, dan kedamaian lingkungan. Kelima kategori ikon citra Indonesia sebagai negara yang indah. Hal ini sesuai dengan slogan resmi yang digunakan oleh Kementerian Pariwisata untuk mempromosikan Indonesia, yaitu Wonderful Indonesia.

Kata kunci: citra, analisis konten, video, youtube 


\section{PENDAHULUAN}

Citra mempunyai arti yang sangat penting bagi sebuah negara. Citra negara akan mempengaruhi kekuatan reputasinya bersaing di tingkat internasional. Reputasi negara yang kuat akan meningkatkan peluang pertumbuhan ekonomi dan hubungan internasional. Pentingnya membangun citra negara Indonesia pun disampaikan oleh Presiden Joko Widodo dalam rapat terbatas Strategi Peningkatan Citra Indonesia di Dunia, pada tanggal 27 September 2016. Rapat tersebut merupakan bentuk tanggapan pemerintah, khususnya Presiden Republik Indonesia tentang buruknya citra Indonesia di mata dunia. Berdasarkan sensus yang dilakukan oleh CEIC \& Statistics Singapore, Indonesia hanya mampu menarik wisatawan mancanegara sebanyak 10 juta orang pada tahun 2015, sedangkan Singapura mampu menggaet 15 juta orang, Malaysia mampu menarik minat wisatawan sebanyak 26 juta orang, dan Thailand mampu menghadirkan 30 juta wisatawan mancanegara. Hasil ini dianggap tidak sebanding dengan kekayaan alam dan budaya Indonesia yang jauh lebih besar dari negara-negara tersebut. Berdasarkan penelitian Future Brand pada tahun 2014 -2015, Indonesia berada di urutan 66 dari 118 negara yang disurvei. Penilaian ini berdasarkan kualitas hidup, potensi bisnis, budaya, pariwisata, sistem nilai, dan kemampuan memproduksi. Data lain dari Good Country Index 2016 menunjukkan bahwa Indonesia berada di peringkat 77 dari 163 negara yang disurvei. Peringkat ini ditentukan berdasarkan sains dan teknologi, kebudayaan, keamanan dan perdamaian internasional, world order, iklim, kemakmuran dan keadilan, serta kesehatan dan kesejahteraan. ${ }^{1}$

Citra negatif Indonesia tersebut mendapat perhatian khusus dari pemerintah. Pada bulan SeptemberDesember 2016, pemerintah melakukan penelitian dalam upaya membentuk citra Indonesia dengan dana sebesar Rp14,275 miliar. Penelitian ini melibatkan 9.902 orang yang tersebar di 15 negara dan satu daerah otonomi khusus, yaitu Indonesia, Australia, Tiongkok, Jepang, Korea Selatan, Singapura, Malaysia, Thailand, India, Uni Emirat Arab, Inggris, Rusia, Jerman, Amerika Serikat, Brazil, dan Hong Kong). Beberapa kementerian pun telah membuat kampanye untuk mempromosikan citra positif Indonesia, salah satunya adalah Kementerian Pariwisata dengan Wonderful Indonesia (Sudarwati, 2016).

Berdasarkan uraian di atas, kita bisa menyimpulkan bahwa kebutuhan Indonesia akan citra atau reputasi positif adalah sangat penting dan mendesak. Seperti apakah citra Indonesia yang dibangun oleh Kementerian Pariwisata? Penelitian ini bertujuan mendeskripsikan citra bangsa Indonesia yang dibentuk oleh Kementerian Pariwisata Republik Indonesia melalui arsip audio visual yang dibuat dan ditampilkan di kanal Youtube resminya, yaitu Indonesia.Travel. Arsip audio visual yang dimaksud adalah video promosi pariwisata milik Kementerian Pariwisata Indonesia yang disimpan dan dipublikasikan di kanal Youtube tersebut. Upaya mengungkap citra Indonesia melalui arsip audio visual Kementerian Pariwisata ini diharapkan mampu memberikan data awal bagi penelitian tentang citra Indonesia melalui teks-teks lainnya.

Merek (brand) adalah gagasan tentang reputasi yang diamati, dihargai, dan dikelola untuk meraih kepercayaan dari pihak lain (Anholt, 2010: 20). Menurut American Marketing Association (AMA), sebuah merek adalah sebuah nama, istilah, tanda, simbol, atau desain, atau kombinasi dari semua istilah ini, yang dimaksudkan untuk mengidentifikasi barang dan jasa dari satu penjual atau sekelompok penjual dan untuk membedakan mereka dari 
para pesaingnya. Bagaimanapun sebuah negara bukanlah produk dalam arti yang sebenarnya. Nation brand tidak menawarkan barang atau jasa yang tangible (nyata, bisa disentuh), melainkan menjadi representasi dari beragam faktor, seperti tempat, sumber daya alam, produk lokal, penduduk, sejarah, budaya, bahasa, sistem politik dan ekonomi, lembaga-lembaga sosial, infrastruktur, tokoh-tokoh, dan citra. Nation brand hanya bisa dibangun melalui peningkatan citra negara yang positif di pasar global. Citra berkaitan dengan cara pandang seseorang atau sekelompok orang terhadap orang lain, kelompok lain, sebuah tempat atau sebuah produk. Citra ditangkap dari proses pengamatan dan interaksi yang berulang-ulang dengan representasi seseorang, sekelompok orang, tempat atau produk. Sebuah negara perlu membangun citra positif yang kuat untuk membentuk nation brand yang kuat, yang akan menjadi payung bagi semua produk yang dihasilkan di sebuah negara untuk bersaing di pasar internasional.

Penelitian tentang citra bangsa atau negara (nation image) dan nation brand Indonesia telah ada sebelumnya. Retno Budi Lestari dan Rini Aprilia (2013) menganalisis model konseptual yang tepat untuk membangun nation brand Indonesia di sektor pariwisata. Pada tahun yang sama, Angela Oscario (2013) mengkaji tentang TVC Wonderful Indonesia sebagai sebagai cermin citra Indonesia di mata dunia. Lutfi Maulana Hakim (2016) meneliti tentang upaya pemerintah Indonesia dalam membangun warisan budaya, yaitu batik, sebagai nation brand Indonesia. Muhammad Nizar Hidayat (2017) membahas tentang kebijakan pemulihan citra Indonesia di masa SBY. Dari keempat penelitian tentang citra dan nation brand Indonesia tersebut, hanya penelitian Angela Oscario beririsan dengan penelitian ini. Hal ini disebabkan obyek kajian yang sama yaitu TVC Wonderful Indonesia. Meskipun demikian, penelitian ini memiliki perbedaan yang terletak jumlah obyek kajiannya. Jika penelitian Angela Oscario menganalisis dua TVC saja, penelitian ini menganalisis semua video di kanal Indonesia.Travel, yaitu 167 TVC, 15 film dokumenter, 33 video publikasi kegiatan, dan 3 video sosialisasi kebijakan.

\section{METODE PENELITIAN}

Penelitian ini menggunakan metode analisis isi (content analysis). Metode analisis isi adalah teknik penelitian untuk membuat kesimpulan yang dapat direplikasi dan valid dari teks ke konteks penggunaannya. Sebagai sebuah teknik, analisis isi menggunakan prosedur khusus yang dapat dipelajari dan terpisah dari otoritas pribadi peneliti. Analisis ini memberikan wawasan baru dan meningkatkan pemahaman peneliti tentang fenomena tertentu (Krippendorff, 2013: 84). Ada tiga prinsip dasar metode analisis isi yaitu objektivitas, sistematis, dan generalisasi. Analisis isi melalui enam langkah, yakni merumuskan pertanyaan dan tujuan penelitian, pemilihan data komunikasi dan sampel, menyusun kategori isi, merumuskan unit analisis, membuat pengkodean, dan menganalisis data.

Data yang digunakan dalam penelitian ini adalah arsip audio visual Kementerian Pariwisata yang diunggah di kanal Youtube Indonesia.Travel. Kanal Youtube ini diperlakukan sebagai tempat penyimpanan arsip (storage) yang dikelola oleh staf Kementerian Pariwisata. Kemudahan akses, kemudahan pengklasifikasian, ketersediaan jaminan keamanan dengan lisensi, dan luasnya kapasitas penyimpanan membuat Youtube menjadi tempat penyimpanan arsip audio visual yang baru dan populer di era digital saat ini. Meskipun demikian, penelitian ini juga memberikan batasan pemilihan kanal Youtube yang memenuhi syaratsyarat tersebut. Kanal Indonesia.Travel 
dianggap memenuhi syarat karena kanal ini dikelola secara resmi oleh pemerintah Indonesia, khususnya Kementerian Pariwisata. Arsip yang disimpan pun memiliki arti penting karena berkaitan dengan upaya pencitraan bangsa. Arsip yang dimaksud adalah video yang dibuat, diunggah, dan dipublikasikan secara resmi oleh Kementerian Pariwisata sebagai sarana promosi pariwisata Indonesia di tingkat nasional dan internasional melalui kanal Youtube Indonesia.Travel. Sejak bulan Oktober 2010 hingga bulan Maret 2018, kanal ini memuat sebanyak 218 video promosi pariwisata yang rata-rata ditonton sebanyak lebih dari 100.000 kali.

Setelah merumuskan pertanyaan dan tujuan penelitian, data yang berupa 218 video dengan durasi rata-rata 3-10 menit disusun dalam kategori-kategori tertentu. Kategori tersebut berdasarkan jenis video dan isi video. Kategorikategori disusun dengan mencantumkan kode-kode pada setiap video. Kategori jenis video iklan diberikan kode TVC (television commercial), yakni TVC5, TVC6, TVC3, dan seterusnya, FD (film dokumenter), yaitu FD1, FD2, FD3 dan seterusnya, PK (publikasi kegiatan) dengan kode PK1, PK2, PK3, dan seterusnya, dan SK (sosialisasi kebijakan) dengan kode SK1, SK2, SK3, dan seterusnya. Sedangkan kategori isi video diberikan kode A (kekayaan alam), yaitu A1, A2, A3, dan seterusnya, B (keragaman budaya), yakni B1, B2, B3, dan seterusnya, $\mathrm{T}$ (tempat) dengan kode $\mathrm{T} 1$, T2, T3, dan seterusnya, dan $P$ (perjalanan) dengan kode P1, P2, P3, dan seterusnya. Langkah selanjutnya adalah menentukan jumlah data yang sesuai dengan kategori-kategori tersebut sehingga didapatkan persentase jumlah video yang pada tahap berikutnya akan dianalisis untuk mengetahui citra Indonesia melalui pembacaan terhadap ikon-ikon yang dihadirkan dalam video.

\section{HASIL DAN PEMBAHASAN}

Globalisasi melahirkan integrasi pasar yang tak dapat ditawar-tawar. Integrasi tersebut melibatkan negaranegara dan teknologi pada tingkat yang tidak pernah disaksikan sebelumnya. Globalisasi memungkinkan individu, perusahaan, dan negara menjangkau seluruh dunia lebih jauh, lebih cepat, lebih dalam, dan lebih murah. Fenomena ini mendorong terjadinya kompetisi antar negara untuk menguasai pasar internasional agar produk-produknya laku terjual sehingga pendapatan negara bertambah dan penduduknya mendapatkan

kesejahteraan. Penguasaan pasar internasional hanya bisa dilakukan jika sebuah negara memiliki keunggulan kompetitif yang tidak dimiliki negara lain. Namun keunggulan kompetitif ini tidaklah cukup untuk menarik pasar internasional, jika sebuah negara tidak memiliki nation brand yang kuat.

Tantangan agar Indonesia unggul di pasar internasional inilah yang mendorong pemerintah untuk melakukan langkah-langkah strategis dalam upaya membangun nation brand yang kuat. Salah satu langkah strategis yang diambil oleh pemerintah Indonesia melalui Kementerian Pariwisata adalah melakukan promosi pariwisata dengan slogan Wonderful Indonesia di berbagai media dan kegiatan, baik di dalam maupun di luar negeri. Di media daring, Kementerian Pariwisata mengelola situs www.indonesia.travel, kanal Youtube Indonesia.Travel, Facebook, dan Twitter dengan nama yang sama. Melalui saluransaluran itu, Kementerian Pariwisata berupaya membangun citra positif Indonesia di mata dunia. Bagian pembahasan ini akan menjelaskan bagaimana Kementerian Pariwisata membentuk citra Indonesia dan seperti apakah citra tersebut dipromosikan melalui kanal Youtube Indonesia.Travel. 
Kanal Youtube Indonesia.Travel menggunggah video sejak tahun 2010. Pada tanggal 3 Mei 2018, kanal ini telah memiliki 71.650 pelanggan (subscribers). Jumlah video yang diunggah adalah sebanyak 218 video. Video pertama di kanal Indonesia.Travel adalah Visit Indonesia Year 2008 Teaser yang diunggah pada tanggal 20 Oktober 2010. Video ini berdurasi 30 detik. Video terakhir yang diunggah saat penelitian ini berlangsung adalah Wonderful Riau Island yang diunggah pada tanggal 19 Maret 2018. Video ini berdurasi 5,02 menit. Berikut ini adalah tampilan beranda kanal Indonesia.Travel, kanal Youtube Resmi Kementerian Pariwisata.

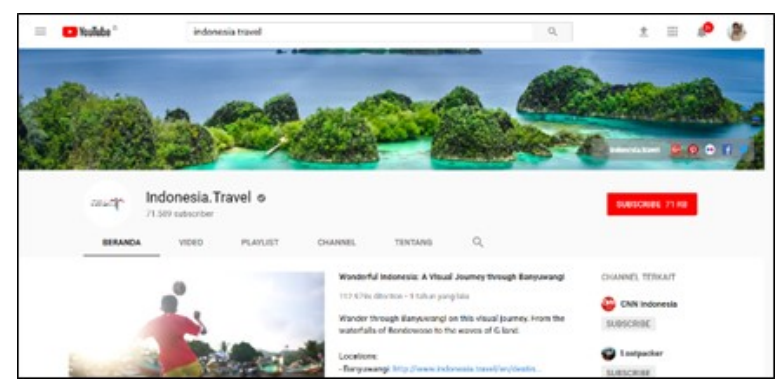

Gambar 1. Beranda Kanal Indonesia.Travel Sumber: https://www.youtube.com/user/ TheIndonesiaTravel

Video-video yang diunggah di kanal Youtube Indonesia.Travel seluruhnya adalah berupa iklan. Jenis-jenis video yang dimuat di kanal Youtube ini disajikan dalam tabel berikut ini.

Tabel 1. Kategori Jenis Video di Kanal Youtube Indonesia.Travel

\begin{tabular}{|c|l|c|c|}
\hline No & Kategori & Jumlah & $\begin{array}{c}\text { Persentase } \\
(\%)\end{array}$ \\
\hline 1 & TVC & 167 & 76.60 \\
\hline 2 & $\begin{array}{l}\text { Film Doku- } \\
\text { menter (FD) }\end{array}$ & 15 & 6.88 \\
\hline 3 & $\begin{array}{l}\text { Publikasi } \\
\text { Kegiatan (PK) }\end{array}$ & 33 & 15.14 \\
\hline 4 & $\begin{array}{l}\text { Sosialisasi Ke- } \\
\text { bijakan (SK) }\end{array}$ & 3 & 1.38 \\
\hline & Jumlah & 218 & 100 \\
\hline
\end{tabular}

Sumber: data diolah
Berdasarkan tabel di atas, kita dapat mengetahui bahwa sebagian besar video yang diunggah di kanal Youtube resmi Kementerian Pariwisata berupa TVC, yaitu sebesar 76,60\%. Sedangkan publikasi kegiatan sebesar 15,14\%, film dokumenter pariwisata sebesar 6,88\%, dan sosialisasi kebijakan hanya sebesar 1,38\%. Iklan dipilih karena dianggap mampu menyampaikan pesan yang penting kepada konsumen dalam jumlah besar secara lebih cepat, dengan durasi yang lebih singkat, dan lebih mengena daripada bentuk komunikasi lainnya. Iklan memungkinkan Kementerian Pariwisata benar-benar terhubung dengan konsumen, yang dalam hal ini adalah masyarakat internasional, sehingga memiliki peluang untuk membangun hubungan berkelanjutan antara konsumen dan merek, yaitu nation brand Indonesia di sektor pariwisata. Iklan adalah pilihan terbaik untuk menciptakan kebutuhan konsumen terhadap sebuah produk, tempat, kegiatan, baik secara sadar maupun tidak sadar. Hal pertama yang bisa dilakukan iklan dalam membangun citra adalah menciptakan kesan yang mendalam. Kesan ini sangat penting untuk menciptakan kebutuhan konsumen akan sebuah merek sehingga tergerak untuk membeli dan menggunakannya, kemudian muncullah kepercayaan yang akan membuatnya kembali membeli dan menggunakan produk dengan merek tersebut.

Kesan yang didapatkan oleh audiens pada saat menonton video di kanal Indonesia.Travel dapat kita temukan pada video reaksi di beberapa kanal Youtube pribadi warga negara asing. Gambar berikut ini adalah beberapa contoh reaksi warga negara asing saat mereka menonton video Wonderful Indonesia. 


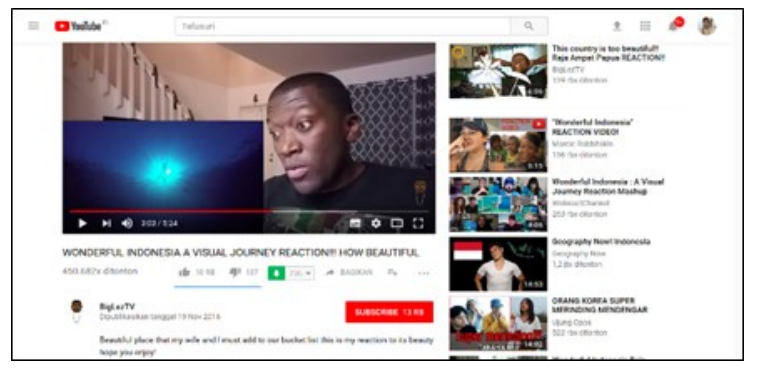

Gambar 2. Reaksi BigLezTV terhadap video Wonderful Indonesia: A Visual Journey Sumber: https://www.youtube.com/watch? $\mathrm{v}=\mathrm{pcfQK} 7 \mathrm{PMU} 4 \mathrm{~g} \& \mathrm{t}=183 \mathrm{~s}$

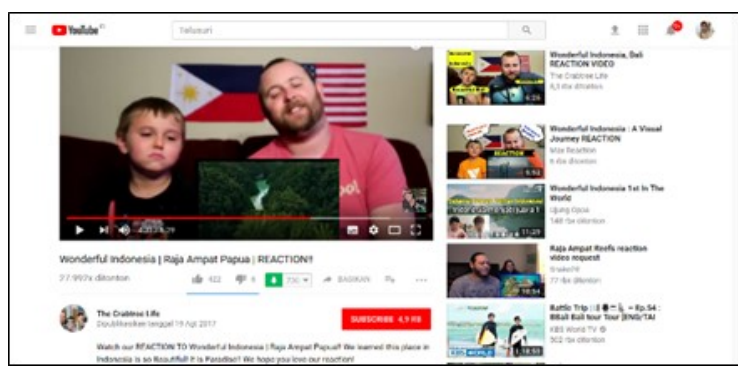

Gambar 3. Reaksi The Crabtree Life terhadap video Wonderful Indonesia: Raja Ampat Papua

Sumber: https://www.youtube.com/watch? $\mathrm{v}=$ Ui09TDOMGRA\& $\mathrm{t}=283 \mathrm{~s}$

Berdasarkan kedua gambar di atas, kita bisa mengetahui bahwa warga negara asing merasa terkesan dengan keindahan Indonesia. Hal ini bisa diketahui dari deskripsi yang ditulis di masing-masing video. BigLezTV menuliskan deskripsi "Beautiful place that my wife and I must add to our bucket list. This is my reaction to its beauty..." dan The Crabtree Life menuliskan, "...We learned this place in Indonesia is so beautiful! It is paradise!..." Kesan yang didapatkan oleh para penonton video tersebut merupakan hasil dari pengolahan materi promosi khas Indonesia, yang tidak dimiliki oleh negara lain (product competitiveness). Kemudahan warga negara asing untuk memahami pesan yang disampaikan dalam video di kanal Youtube Indonesia.Travel tidak hanya karena kualitas gambar, copy, dan backsound yang menarik, tetapi juga adanya dukungan penggunaan bahasa asing pada sebagian besar video promosi pariwisata di kanal ini. Dari 218 video, sebanyak 171 video berbahasa Inggris (78,44\%), 34 video berbahasa Indonesia (15,59\%), 10 video berbahasa Jepang (4,59\%), 1 video berbahasa Mandarin $(0,46 \%), 1$ video berbahasa Korea $(0,46 \%)$, dan 1 video berbahasa Belanda $(0,46 \%)$. Berdasarkan persentase ini, kita dapat mengetahui bahwa target audiens kanal Indonesia.Travel adalah warga negara asing. Penggunaan bahasa asing dalam video promosi merupakan pilihan yang tepat untuk memperkenalkan Indonesia secara global.

Materi promosi di kanal youtube ini sangat beragam, mulai dari kekayaan alam, keragaman budaya, profil daerah tujuan wisata, travel vlog, paket wisata, dan kegiatan wisata dikategorikan dalam perjalanan dengan kode P. Berikut adalah tabel kategori materi promosi di kanal Youtube Indonesia.Travel.

Tabel 2. Kategori Materi Promosi di Kanal Youtube Indonesia.Travel

\begin{tabular}{|c|l|c|c|}
\hline $\begin{array}{c}\text { N } \\
\mathbf{0}\end{array}$ & \multicolumn{1}{|c|}{ Kategori } & Jumlah & $\begin{array}{c}\text { Persentase } \\
(\mathbf{\%})\end{array}$ \\
\hline 1 & $\begin{array}{l}\text { Keindahan } \\
\text { Alam (A) }\end{array}$ & 14 & 6.422 \\
\hline 2 & $\begin{array}{l}\text { Keragaman Bu- } \\
\text { daya (B) }\end{array}$ & 44 & 20.183 \\
\hline & $\begin{array}{l}\text { Perpaduan } \\
\text { Kekayaan Alam } \\
\text { \& Keragaman } \\
\text { Budaya: } \\
\text { Tempat (T) } \\
\text { Perjalanan (P) }\end{array}$ & $\begin{array}{c}53 \\
107\end{array}$ & $\begin{array}{l}24.312 \\
49.083\end{array}$ \\
\hline & Jumlah & 218 & 100 \\
\hline
\end{tabular}

Sumber: data diolah

Pembagian kategori seperti yang tersaji dalam tabel di atas dibuat berdasarkan materi yang paling menonjol, yang dimuat dalam video-video tersebut. Secara umum, pada setiap video terdapat perpaduan materi sehingga unsur alam, budaya, tempat, dan perjalanan bisa muncul bersamaan pada sebuah video, meskipun durasinya sangat singkat. Berdasarkan tabel tersebut, kita 
bisa membaca bahwa kategori perjalanan mempunyai porsi yang cukup besar yaitu $49,083 \%$. Sementara itu, kategori tempat memiliki porsi sebesar $24,312 \%$, kategori keragaman budaya sebesar 20,183\%, dan kategori kekayaan alam sebesar 6,422\%.

Sesuai dengan slogan promosi yang telah ditetapkan oleh Kementerian Pariwisata, yaitu Wonderful Indonesia, video-video yang diunggah di kanal Youtube Indonesia.Travel mempromosikan pesona Indonesia. Indonesia sebagai negara yang mempesona adalah citra yang ingin dibangun oleh Kementerian Pariwisata. Gagasan tentang keindahan Indonesia ini dapat ditemukan dalam beragam ikon yang tersebar pada setiap materi video. Berikut adalah tabel sebaran ikon keindahan Indonesia yang bisa ditemukan di kanal Indonesia.Travel.

Sumber: data diolah gambaran keindahan alam yang ditampilkan dalam video Wonderful Indonesia: Nature \& Ecotourism di kanal Indonesia.Travel.

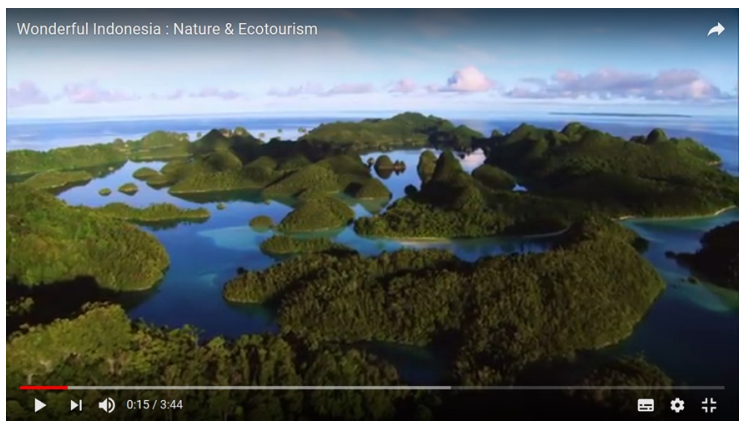

Gambar 4. Gugusan Pulau sebagai Salah Satu Ikon Keindahan Alam Indonesia

Sumber: https://www.youtube.com/watch? $\mathrm{v}=\mathrm{odKKYryIAPs} \& \mathrm{t}=15 \mathrm{~s}$

Pesona Indonesia juga ditampilkan dalam bentuk keunikan budaya Indonesia, yang tidak dimiliki oleh negara lain di dunia. Ikon-ikon yang umumnya

Tabel 3. Kategori Ikon Pesona Indonesia yang Ditampilkan di Kanal Youtube Indonesia.Travel

\begin{tabular}{|c|c|c|c|c|c|}
\hline No & Kategori & A & B & $T$ & $\mathbf{P}$ \\
\hline 1 & $\begin{array}{l}\text { Keindahan Alam } \\
\text { (gunung, pantai, padang rumput, kawah, danau, } \\
\text { laut, hutan tropis, air terjun, flora, fauna) }\end{array}$ & $\mathrm{x}$ & & $\mathrm{x}$ & $\mathrm{x}$ \\
\hline 2 & $\begin{array}{l}\text { Keunikan Budaya } \\
\text { (upacara adat, tari tradisional, kerajinan tangan, } \\
\text { ragam suku) }\end{array}$ & & $\mathrm{x}$ & $\mathrm{x}$ & $\mathrm{x}$ \\
\hline 3 & $\begin{array}{l}\text { Keramahan Penduduk } \\
\text { (WNI tersenyum, tertawa, berjabat tangan, } \\
\text { mengangguk) }\end{array}$ & & $\mathrm{x}$ & $\mathrm{x}$ & $\mathrm{x}$ \\
\hline 4 & $\begin{array}{l}\text { Kelezatan Makanan } \\
\text { (makanan tradisional, ekspresi saat makan) }\end{array}$ & & & $\mathrm{x}$ & $\mathrm{x}$ \\
\hline 5 & $\begin{array}{l}\text { Kedamaian/ Keamanan Lingkungan } \\
\text { (ekspresi aktor/ aktris saat menikmati perjalan- } \\
\text { an: mata tertutup, tersenyum, gerakan meditasi) }\end{array}$ & $\mathrm{x}$ & $\mathrm{x}$ & $\mathrm{x}$ & $\mathrm{x}$ \\
\hline
\end{tabular}

Sumber: data diolah

Berdasarkan tabel di atas, pesona Indonesia digambarkan dengan ikon keindahan alam, keragaman budaya, keramahan penduduk, kelezatan makanan, serta kedamaian dan keamanan lingkungan. Keindahan alam yang sering ditampilkan adalah gugusan pulau, gunung, pantai, padang rumput, kawah, danau, laut, hutan tropis, air terjun, flora, dan fauna khas Indonesia. Berikut ini adalah salah satu contoh dimunculkan adalah upacara adat, tari tradisional, kerajinan tangan, ragam suku di Indonesia, dari Sabang sampai Merauke. Berikut ini adalah salah satu contoh keunikan budaya Indonesia dalam video Wonderful Indonesia: The Journey to a Wonderful World di kanal Indonesia.Travel.

Pesona Indonesia yang lainnya bisa ditemukan dalam tingkah laku dan tutur kata penduduknya yang ramah. 


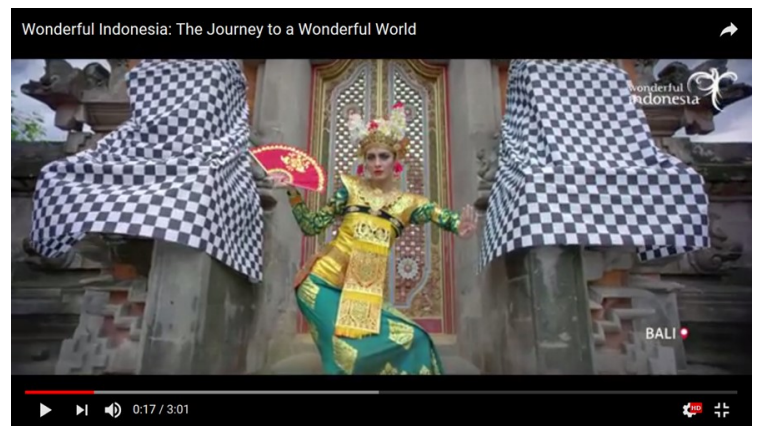

Gambar 5. Penari Bali sebagai Salah Satu Ikon Keunikan Budaya Indonesia Sumber: https://www.youtube.com/watch? $\mathrm{v}=\mathrm{TT} 8 \mathrm{~J} 3 \mathrm{wUX} \mathrm{YY}$

Keramahan penduduk Indonesia bisa dilihat beberapa video di kanal Indonesia.Travel yang menampilkan ekspresi wajah yang selalu tersenyum, sedang tertawa, gerakan berjabat tangan, menangkupkan telapak tangan di dada sambil mengangguk dan tersenyum, serta uluran tangan mereka saat membantu wisatawan di sebuah tempat wisata. Berikut ini adalah salah satu tampilan keramahan penduduk Indonesia dalam video Wonderful Indonesia: A Visual Journey.

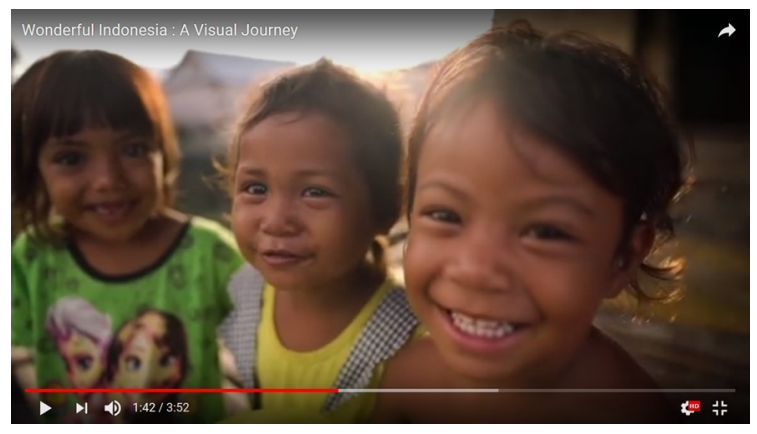

Gambar 6. Senyum Anak-Anak sebagai Salah Satu Ikon Keramahan Penduduk Indonesia Sumber: https://www.youtube.com/watch? $\mathrm{v}=0 \mathrm{QjbArbuN} 4 \mathrm{E}$

Indonesia yang mempesona tidak hanya karena keindahan alam, keunikan budaya, dan keramahan penduduknya. Pesona Indonesia juga mencakup keragaman kuliner nusantara. Kelezatan makanan Indonesia pun dihadirkan dalam beberapa video di kanal Indonesia.travel. Berikut ini merupakan salah satu gambaran kelezatan makanan
Indonesia dalam video Wonderful Indonesia: Sensory.

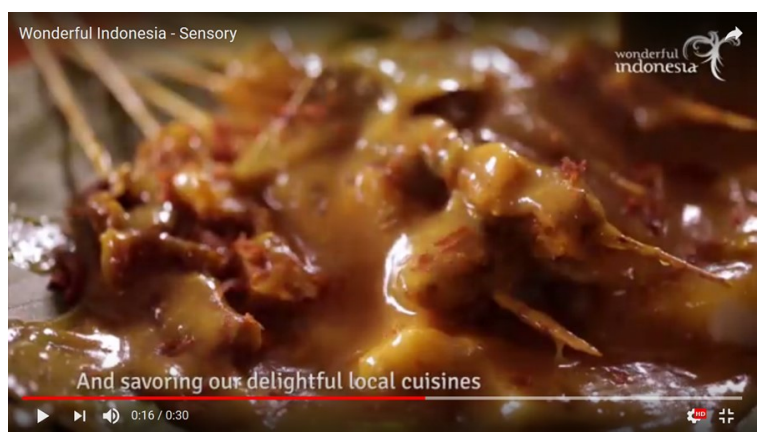

Gambar 7. Sate sebagai Salah Satu Ikon Kelezatan Makanan Indonesia

Sumber: https://www.youtube.com/watch? $\mathrm{v}=\mathrm{bkz} 8 \mathrm{bH} 80 \mathrm{M}-\mathrm{E}$

Selain itu, Indonesia yang mempesona juga bisa dinikmati karena kedamaian atau keamanan lingkungannya sehingga siapapun bisa berkunjung ke Indonesia tanpa rasa takut. Kedamaian/ keamanan lingkungan diwujudkan dalam tampilan ekspresi aktor/ aktris dalam video di kanal Indonesia.Travel, saat mereka melihat dan menikmati kekayaan alam, keragaman budaya, keramahan penduduk, dan kelezatan makanan. Ekspresi tersebut adalah tersenyum sambil merentangkan kedua tangan, memejamkan mata sambil tersenyum, memejamkan mata sambil merentangkan kedua tangan, dan gerakan-gerakan meditasi. Berikut ini merupakan salah satu contoh gambaran kedamaian yang bisa dirasakan wisatawan saat berkunjung ke Indonesia, yang dihadirkan dalam video Wonderful Indonesia: The More You Feel, The More You Know.

Secara umum, semua ikon pesona Indonesia dapat muncul dalam setiap kategori video, meskipun dengan proporsi berbeda. Dalam video yang menonjolkan keindahan alam misalnya, ikon keunikan budaya, keramahan penduduk, kelezatan makanan, dan kedamaian/ keamanan lingkungan akan 


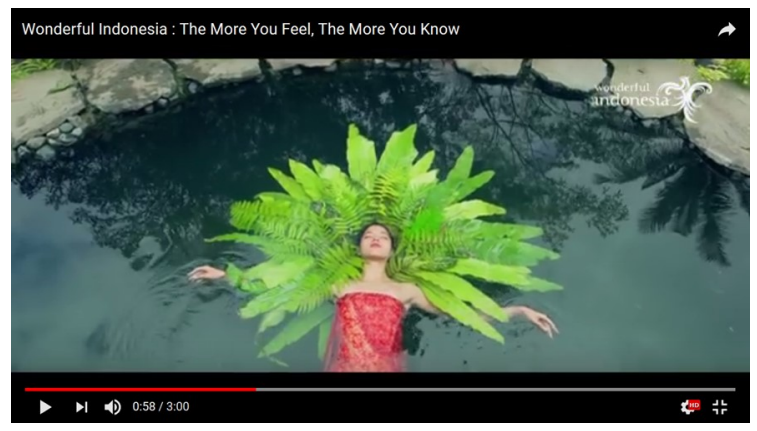

Gambar 8. Gerakan Memejamkan Mata sebagai Salah Satu Ikon Kedamaian/ Keamanan Lingkungan Indonesia

Sumber: https://www.youtube.com/watch? $\mathrm{v}=$ QvuWWIqY6Vg

muncul dengan durasi yang lebih singkat. Ikon-ikon pesona Indonesia akan muncul dengan proporsi yang berimbang dalam kategori tempat dan perjalanan yang memadukannya untuk menghadirkan kesan takjub bagi audiens yang menontonya.

Berdasarkan uraian di atas, kita bisa mengetahui bahwa citra negara yang berusaha diciptakan dan dipromosikan oleh Kementerian Pariwisata kepada masyarakat dunia secara jelas tercantum dalam slogan Wonderful Indonesia. Slogan ini menjadi jiwa dalam setiap video yang dibuat dan dipublikasikan di kanal Youtube resminya, yaitu Indonesia.Travel. Wonderful Indonesia atau pesona Indonesia dimaknai sebagai sebuah janji bagi khalayak internasional bahwa Indonesia adalah sebuah negara yang akan membuat setiap orang merasa takjub, senang, dan selalu ingin merasakan pengalaman baru saat mengunjunginya karena kekayaannya yang melimpah, baik sumber daya alam maupun sumber daya manusianya.

\section{KESIMPULAN}

Citra Indonesia yang dibangun oleh Kementerian Pariwisata adalah Indonesia sebagai negara yang mempesona. Cara yang dilakukan untuk membangun citra tersebut adalah membuat dan mengelola arsip audio visual berupa video promosi pariwisata yang diunggah dan dipublikasikan melalui kanal Youtube resmi Kementerian Pariwisata, yaitu Indonesia.Travel. Video-video tersebut dibuat dengan memadukan ikon-ikon yang mewakili pesona Indonesia, seperti keindahan alam, keunikan budaya, keramahan penduduk, kelezatan makanan, dan kedamaian/ keamanan lingkungan. Upaya untuk menjangkau masyarakat global secara luas juga dilakukan dengan penggunaan bahasa asing, khususnya bahasa Inggris pada hampir seluruh video di kanal Youtube Indonesia.Travel. Slogan Wonderful Indonesia yang telah ditetapkan Kementerian Pariwisata sejak tahun 2011 merupakan rumusan nyata citra Indonesia yang dipromosikan di tingkat Internasional dan diharapkan mampu menguatkan nation brand Indonesia untuk meraih kepercayaan masyarakat global.

\section{DAFTAR PUSTAKA}

\section{Pustaka Jurnal Penelitian}

Fan, Ying. (2005). Branding the nation: What is being branded? Journal of Vacation Marketing. Vol. 12 No. 1, 2006, halaman 5-14. London, Thousand Oaks, CA, and New Delhi: Sage Publications.

Hakim, Lutfi Maulana. (2016). Politik Membangun Warisan Budaya bangsa Indonesia sebagai Nation Brand (Studi Kasus: Batik sebagai Brand dan Identitas Indonesia). Tesis S2 Ilmu Hubungan Internasional. Universitas Gadjah Mada.

Hidayat, Muhammad Nizar. (2017). Analisis Kebijakan Pemulihan Citra Indonesia pada Masa Kepemimpinan Presiden SBY. Jurnal Administrative Reform Vol. 4, No.2 halaman 227-242.

Lestari, Retno Budi, dan Aprilia, Rini. (2013). Membangun Nation 
Branding dalam Upaya Meningkatkan Daya Saing Sektor Pariwisata Indonesia. Proceeding PESAT (Psikologi, Ekonomi, Sastra, Arsitektur \& Teknik Sipil) Vol. 5, halaman 358-366.

Sudarwati, Yuni. (2016). Pentingnya Riset untuk Peningkatan Citra Indonesia. Majalah Info Singkat Ekonomi dan Kebijakan Publik, Pusat Penelitian Badan Keahlian DPR RI, Vol. VIII. No.19.

\section{Pustaka Buku}

Anholt, Simon. (2010). Places, Identity, Image, and Reputation. New York: Palgrave Macmillan.

Krippendorff, Klaus. (2013). Content Analysis: An Introduction to Its Methodology. Third Edition. London, Thousand Oaks, CA, and New Delhi: Sage Publications.

\section{Sumber Internet}

BigLezTV. (2016). Wonderful Indonesia A Visual Journey Reaction How Beautiful. www.youtube.com/watch? $\mathrm{v}=\mathrm{pcfQK} 7 \mathrm{PMU} 4 \mathrm{~g} \& \mathrm{t}=183 \mathrm{~s}$ )

Indonesia.Travel. (2018). Beranda. Kementerian Pariwisata Republik Indonesia www.youtube.com/user/ TheIndonesiaTravel).

(https://

(2015). Wonderful Indonesia: Nature \& Ecotourism. Kementerian Pariwisata Republik Indonesia www.youtube.com/watch? $\mathrm{v}=0 \mathrm{dKKYryIAPs} \& \mathrm{t}=15 \mathrm{~s}$ ).

Indonesia: A Visual Journey. Kementerian Pariwisata Republik Indonesia www.youtube.com/watch? $\mathrm{v}=0$ jQbArbuN4E).
(2016) Wonderful

Indonesia: The Journey to a Wonderful world. Kementerian Pariwisata Republik Indonesia (https://www.youtube.com/watch? $\mathrm{v}=\mathrm{TT} 8$ ]3wUX YY).

(2017). Wonderful

Indonesia: Sensory. Kementerian Pariwisata Republik Indonesia (https://www.youtube.com/watch? $\mathrm{v}=\mathrm{bkz} 8 \mathrm{bH} 80 \mathrm{M}-\mathrm{E})$. (2018). The More You feel, the More You Know. Kementerian Pariwisata Republik Indonesia (https:// www.youtube.com/watch? $\mathrm{v}=$ QvuWWIqY6Vg).

Kementerian Sekretarian Negara RI. (2016). Membangun Harga Diri Bangsa, Membangun Citra Bangsa. (http://www.presidenri.go.id/ berita-aktual/membangun-hargadiri-bangsa-memperbaiki-citrabangsa.html).

The Crabtree Life. (2017). Wonderful Indonesia Raja Ampat Papua Reaction. (https:// www.youtube.com/watch? $\mathrm{v}=$ Ui09TDOMGRA\&t=283s) 